\title{
Copper Compounds Influence in Vitro Rooting of Birch Microcuttings
}

\author{
Michael A. Arnold ${ }^{1}$, R. Daniel Lineberger ${ }^{2}$, and Daniel K. Struve ${ }^{3}$ \\ Department of Horticulture, The Ohio State University, 2001 Fyffe Court, Columbus, OH 43210-1096 \\ Additional index words. Betula pubescens $\times$ papyrifera, cupric sulfate, cupric chloride, cupric acetate, cupric carbonate, \\ micronutrient, copper toxicity, rhizogenesis, root regeneration
}

\begin{abstract}
The effects of woody plant medium (WPM) with various formulations and concentrations of $\mathrm{Cu}^{+2}$ on in vitro rooting and subsequent shoot growth of microcuttings of a Betu pubescens $\times$ papyrzfera (birch) clone were monitored for 28 days. Adventitious root initiation and elongation were reduced in magnitude and slowed in development by moderate to high $\mathrm{Cu}\left(\right.$ as $\left.\mathrm{CuSO}_{4} \cdot 5 \mathrm{H}_{2} \mathrm{O}\right)$ concentrations, with near zero root regeneration occurring at $157 \mu \mathrm{M} \mathrm{Cu}$. Shoot growth was also inhibited by $157 \mu \mathrm{M}$ Cu as cupric sulfate. Copper-toxicity symptoms (senescent leaves, necrotic stems, and bulbous and stunted roots) were significantly increased by moderate to high levels ( $\geq 79 \mu \mathrm{M}$ ) of $\mathrm{Cu}$ as cupric sulfate. Microcuttings responded differently to $\mathrm{Cu}^{+2}$ applied as cupric chloride $\left(\mathrm{CuCl}_{2} \cdot 2 \mathrm{H}_{2} \mathrm{O}\right)$. Root initiation, root elongation, and root branching were increased by moderate concentrations of $\mathrm{Cu}$ as cupric chloride. Shoot growth was slightly stimulated by cupric chloride at moderate levels. No significant increase in $\mathrm{Cu}$-toxicity symptoms was observed at concentrations up to $157 \mu \mathrm{M} \mathrm{Cu}$ as cupric chloride. Cupric acetate $\left[\mathrm{Cu}\left(\mathrm{CH}_{3} \mathrm{COO}\right) ; \mathrm{H}_{2} \mathrm{O}\right]$ and cupric carbonate $\left[\mathrm{CuCO} \cdot \mathrm{Cu}(\mathrm{OH})_{2}\right]$ produced more severe $\mathrm{Cu}$-toxicity symptoms than cupric sulfate. Root regeneration and shoot growth were inhibited and increased $\mathrm{Cu}$-toxicity symptoms were apparent even with low concentrations $(39 \mu \mathrm{M})$ of $\mathrm{Cu}$ as cupric acetate or cupric carbonate. There was little or no effect on root regeneration when the $\mathrm{Cu}^{+2}$ in cupric sulfate was replaced by different cations, i.e., magnesium sulfate $\left(\mathrm{MgSO}_{4} \cdot 7 \mathrm{H}_{2} \mathrm{O}\right)$, calcium sulfate $\left(\mathrm{CaSO}_{4} \cdot \mathbf{2 H}_{2} \mathrm{O}\right)$, and sulfuric acid $\left(\mathrm{H}_{2} \mathrm{SO}_{4}\right)$, a result suggesting that the observed responses could be attributed to the $\mathrm{Cu}^{+2}$ concentration. Changes in media $\mathrm{pH}$ did not correspond to $\mathrm{Cu}$-toxicity symptoms or alterations in root or shoot growth by the $\mathrm{Cu}$ compounds.
\end{abstract}

The concentrations of $\mathrm{Cu}$ necessary for plant growth are very low. Neales (1959) obtained normal growth of excised flax (Linum usitatissimum L.) roots on a medium containing $0.005 \mathrm{mg} \mathrm{Cu} / \mathrm{liter}$ $(\approx 0.08 \mu \mathrm{M})$. Brandenburg, in Stiles (1961), reported normal vegetative growth of Avena sativa $\mathrm{L}$. in solution cultures containing $0.020 \mathrm{mg} \mathrm{Cu} /$ liter $(\approx 0.3 \mu \mathrm{M})$ and normal reproductive growth with $0.050 \mathrm{mg} \mathrm{Cu} /$ liter $(\approx 0.8 \mu \mathrm{M})$. Ozolina (1988) reported that, in solution culture, growth responses of cereal roots to cupric sulfate were concentration dependent; low concentrations stimulated root elongation, while higher concentrations changed root morphology and eventually inhibited root growth. Common tissue-culture rooting media such as Murashige and Skoog (Murashige and Skoog, 1962) and woody plant medium (WPM) (Lloyd and McCown, 1980) contain $0.064 \mathrm{mg} \mathrm{Cu} / \mathrm{liter}(1.007 \mu \mathrm{M})$ as cupric sulfate. The effects of alternative formulations and concentrations of $\mathrm{Cu}^{+2}$ on in vitro rooting of woody plant microcuttings are unknown.

The objectives of this experiment were to 1) develop a dose response curve for $\mathrm{Cu}^{+2}$ as cupric sulfate with respect to rooting Betula pubescens $\times$ papyrifera microcuttings in WPM; 2) determine if the dose response curve of microcutting root regeneration to increased $\mathrm{Cu}$ levels differed among various formulations of $\mathrm{Cu}^{+2}$; and 3) determine whether concentration-dependent root growth responses to cupric sulfate were attributable to the sulfate anion.

Received for publication 18 Sept. 1992. Accepted for publication 28 May 1993. Manuscript no. 225-90, Ohio Agricultural Research and Development Center, The Ohio State Univ. The use of trade names in this publication does not imply endorsement by the authors, TAMU, or OARDC of the products named, nor criticism of similar ones not mentioned. We acknowledge the technical assistance of Joseph Takayama. The cost of publishing this paper was defrayed in part by the payment of page charges. Under postal regulations, this paper therefore must be hereby marked advertisement solely to indicate this fact.

${ }^{1}$ Assistant professor. Present address: Dept. of Horticultural Sciences, Texas A \& M Univ., College Station, TX 77843-2133.

${ }^{2}$ Professor. Present address: Dept. of Horticultural Sciences, Texas A \& M Univ., College Station, TX 77843-2133

${ }^{3}$ Associate professor.

\section{Materials and Methods}

Copper formulations (Expt. 1). This experiment was designed to determine whether alternative formulations of $\mathrm{Cu}^{+2}$, i.e., cupric chloride, cupric acetate, and cupric carbonate, would induce dose response curves similar to that of cupric sulfate. Microcuttings (2.0 $\mathrm{cm}$ ) were taken from proliferating birch shoot cultures (Mount Alto Pennsylvania State Forestry Nursery clone 247, an easily rooted clone) maintained on WPM salts and vitamins with $11.1 \mu \mathrm{M}$ benzyladenine (BA), $7 \mathrm{~g}$ Difco Bacto agar/liter, and $30 \mathrm{~g}$ sucrose/ liter. Proliferating shoot cultures were subculture to fresh medium every 3 weeks. Microcuttings were taken from actively growing single stems with four to seven partially to fully expanded leaves and no visible signs of root development. The basal $1 \mathrm{~cm}$ of each microcutting was inserted into $12.5 \mathrm{ml}$ of the rooting medium in $25 \times 150$-mm clear pyrex culture tubes. The tubes were sealed with clear plastic snap-on caps. The rooting medium was the same as for shoot cultures, except BA was omitted and $\mathrm{Cu}$ (as cupric sulfate, cupric chloride, cupric acetate, or cupric carbonate) was added. After $\mathrm{Cu}$ was added, the medium $\mathrm{pH}$ was adjusted to 5.3 with $1 \mathrm{~N} \mathrm{HCl}, 1$ $\mathrm{N} \mathrm{NaOH}$, or both, then autoclave at $121 \mathrm{C}$ for $20 \mathrm{~min}$.

A preliminary experiment (data not presented) indicated that the rooting response range of birch microcuttings to cupric sulfate was 39 to $157 \mu \mathrm{M} \mathrm{Cu}$. Thus, treatments were a control WPM ( 1.0 $\mu \mathrm{M} \mathrm{Cu}$ as cupric sulfate) and WPM with added $\mathrm{Cu}$ in the forms of cupric sulfate, cupric chloride, cupric acetate, or cupric carbonate to produce media containing $39,79,118$, and $157 \mu \mathrm{M} \mathrm{Cu}$ for each of the four formulations. Two blocks of 10 cuttings per formulation and concentration combination were placed in the culture room in a randomized complete-block design. Each experiment in this study was conducted twice. The culture room was maintained at 23 $\pm 2 \mathrm{C}$. Illumination was for $16 \mathrm{~h} /$ day at $40 \mu \mathrm{mol} \cdot \mathrm{m}^{-2} \cdot \mathrm{s}^{-1}$ photosynthetically active radiation from cool-white fluorescent lamps.

The total number of roots and the number of roots $\geq 0.5 \mathrm{~cm}$ long were recorded at $0,7,14,21$, and 28 days after the microcuttings were inserted into the culture tubes. After 28 days, cuttings were 
harvested and total length of primary adventitious roots (excluding second-and higher-order roots), total shoot length, and presence of root branching (one or more second-order roots) were recorded, Measures of $\mathrm{Cu}$ toxicity included the presence of chlorotic, necrotic, or abscissed leaves and the presence of necrotic lesions on the stems.

Medium $\mathrm{pH}$ (Expt. 2). Changes in medium $\mathrm{pH}$ were monitored using a combination $\mathrm{pH}$ electrode standardized to $65 \mathrm{C}$ so that medium $\mathrm{pH}$ could be monitored in the presence of molten agar. Media were prepared as in Expt. 1 for each concentration of cupric sulfate, cupric chloride, cupric acetate, and cupric carbonate. As in the previous experiment, all media were brought to $\mathrm{pH} 5.3$ before being autoclave. Medium $\mathrm{pH}$ was determined on four replications of each treatment combination immediately after autoclaving and 7 and 28 days thereafter.

Sulfate formulations (Expt. 3). This experiment was designed to determine whether the accompanying sulfate anion affected plant responses. Equimolar amounts of sulfate in the form of cupric sulfate, calcium sulfate, magnesium sulfate, and sulfuric acid were added to WPM to produce media containing concentrations of sulfate equal to those added for the cupric sulfate treatments in Expt. 1, i.e., $39,79,118$, and $157 \mu \mathrm{M} \mathrm{SO}_{4}$. Conditions were as described in Expt. 1. The three experiments were analyzed separately using factorial analysis of variance, polynomial regression, and full quadratic response surface modeling (SAS Institute, 1988).

\section{Results and Discussion}

There were significant $(P \leq 0.05)$ interactions among the $\mathrm{Cu}$ formulations, $\mathrm{Cu}$ concentrations, and rooting times for the number of roots and number of roots $20.5 \mathrm{~cm}$ long. Significant $(P \leq 0.05)$ interactions among the $\mathrm{Cu}$ formulations and $\mathrm{Cu}$ concentrations were found for root length, the number of cuttings with branched roots, the number of cuttings with senescent leaves, the number of cuttings with necrotic stems, and shoot length. Although treatment effects on shoot length were statistically significant $(P \leq 0.05)$, differences among treatments were $\leq 0.5 \mathrm{~cm}$; thus, shoot length data are not presented.

Copper formulations. Similar growth and toxicity responses were observed in Expts. 1 and 3 when $\mathrm{Cu}$ was supplied as cupric sulfate (Figs. 1-5, Table 1). Adventitious root initiation, as measured by the number of roots regenerated per cutting (Fig. 1A), was reduced in magnitude and developed more slowly with $\mathrm{Cu}$ concentrations exceeding $\approx 39 \mu \mathrm{M} \mathrm{Cu}$ as cupric sulfate. Root elongation rates, as measured by root length per cutting (Fig. 2A), were slowed by increased cupric sulfate concentrations and approached zero at $157 \mu \mathrm{M} \mathrm{Cu}$ as cupric sulfate. The number of cuttings with branched roots was reduced slightly by low to moderate concentrations of $\mathrm{Cu}$ as cupric sulfate, then decreasing rapidly to near zero at higher concentrations (Fig. 2B). Shoot length was slightly reduced (by $0.25 \mathrm{~cm}$ ) by $\mathrm{Cu}$ as cupric sulfate, but only at the highest
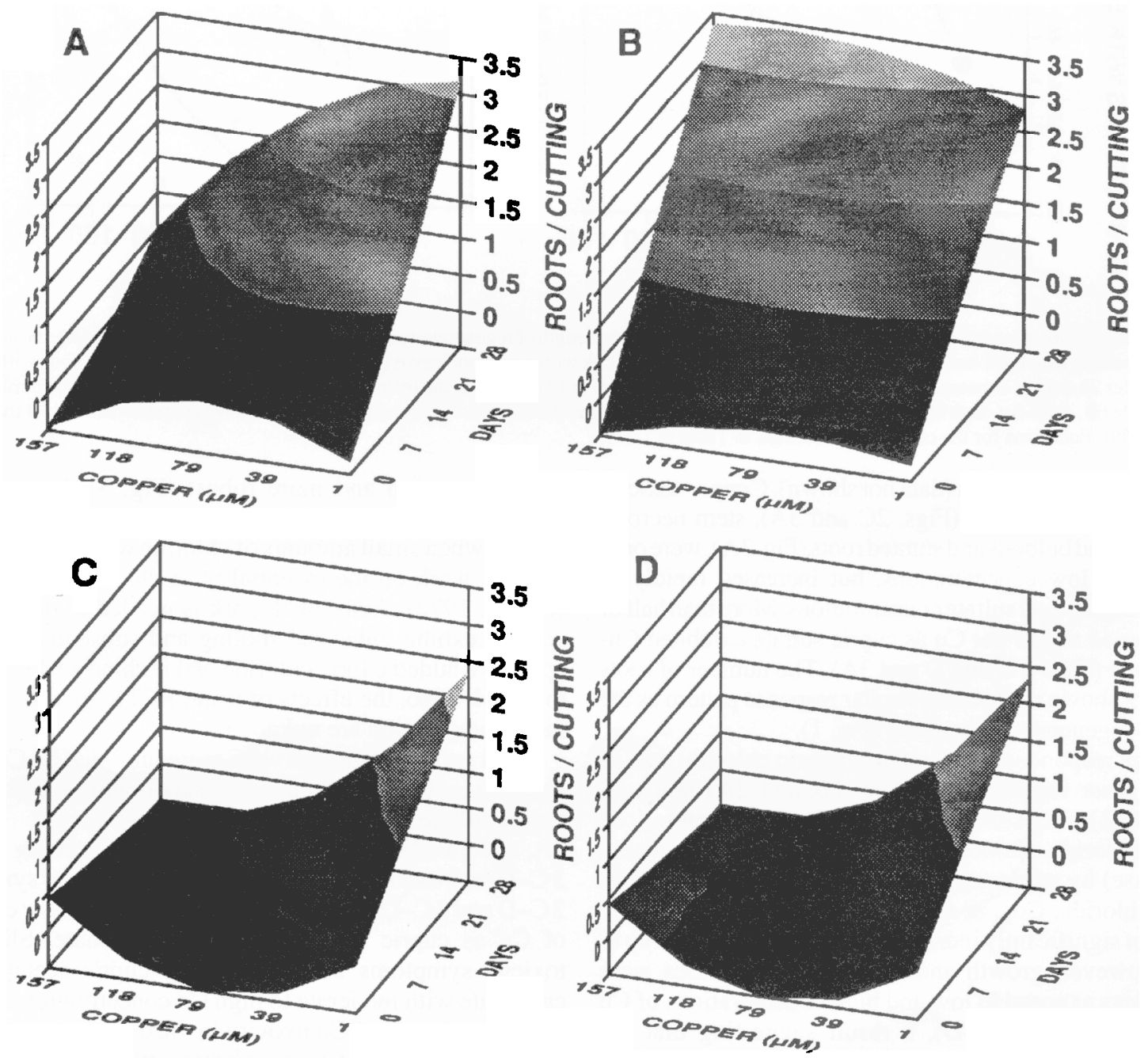

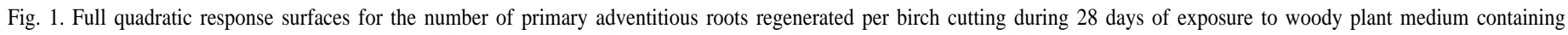
increased $\mathrm{Cu}$ concentrations as cupric sulfate (A), cupric chloride (B), cupric acetate (C), and cupric carbonate (D). Response surface equations are presented in Table 1. 

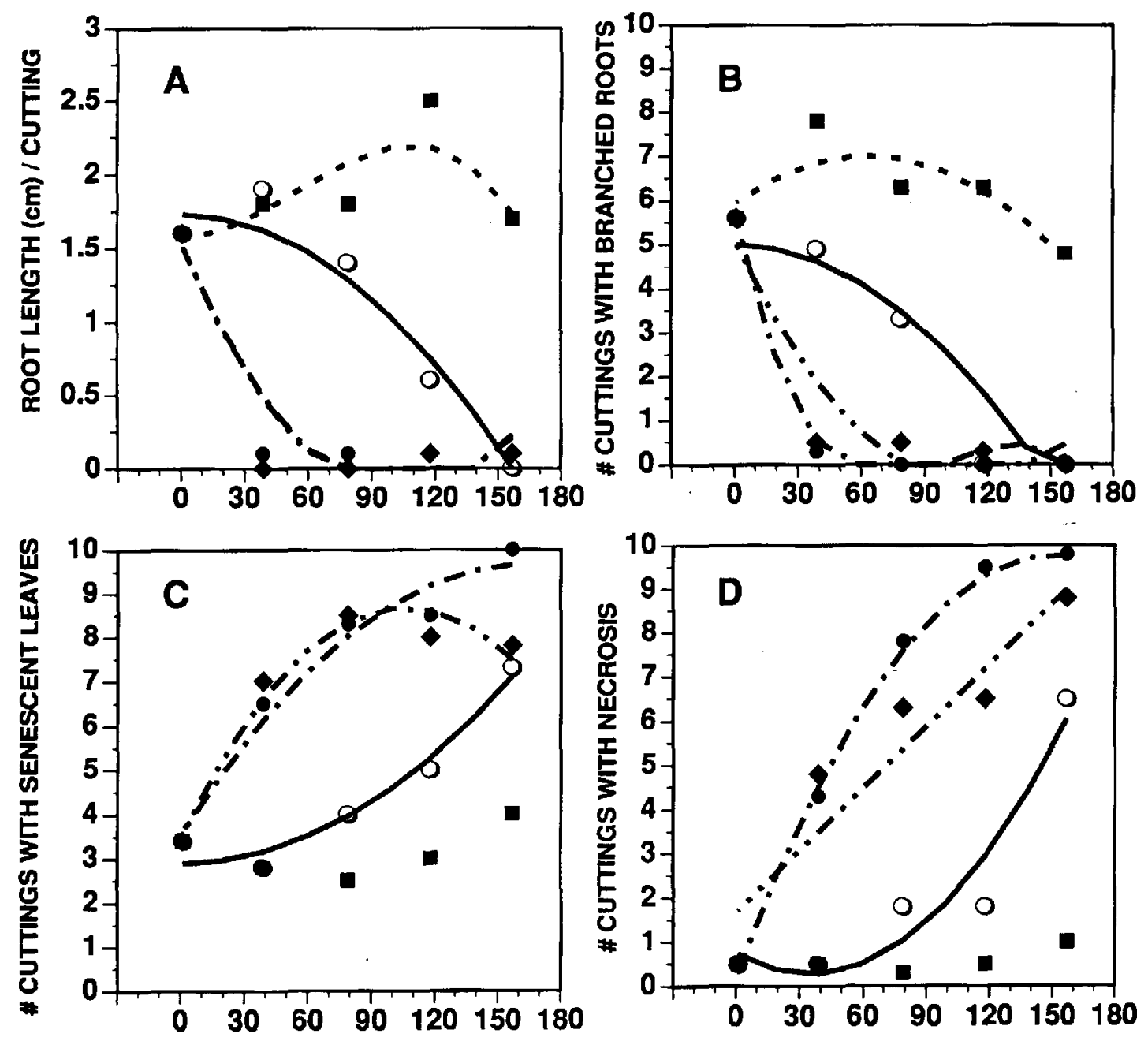

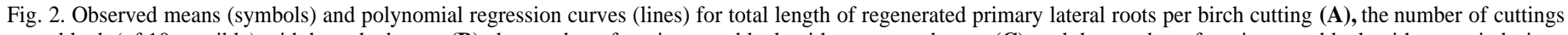

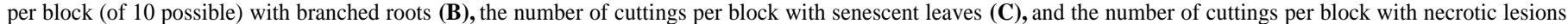

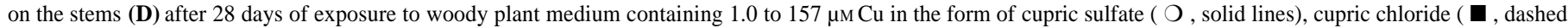

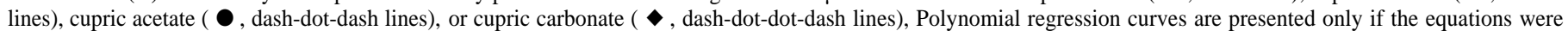
significant $(P \leq 0.05)$. Equations for the curves are-presented in Table 1 .

concentration tested- $157 \mu \mathrm{MCu}$ (data not shown). Copper-toxicity symptoms, i.e., leaf senescence (Figs. 2C and 3A), stem necrosis (Figs. 2D and 3A), and bulbous and stunted roots (Fig. 3A), were only slightly affected at low concentrations, but increased rapidly in occurrence with high cupric sulfate concentrations. More than half of the cuttings exposed to $157 \mu \mathrm{M} \mathrm{Cu}$ as cupric sulfate exhibited $\mathrm{Cu}$ toxicity symptoms (Figs. $2 \mathrm{C}$ and $\mathrm{D}$ and $3 \mathrm{~A}$ ). The number of roots $20.5 \mathrm{~cm}$ (data not shown) followed a similar response pattern as the number of roots regenerated per cutting (Fig, 1).

Microcuttings responded differently to cupric chloride than to cupric sulfate. Root regeneration (Figs. $1 \mathrm{~B}$ and $2 \mathrm{~A}$ ) and root branching (Fig. 2B) were stimulated by moderate concentrations of $\mathrm{Cu}$ as cupric chloride. Shoot elongation was slightly stimulated $(0.25 \mathrm{~cm}$ increase) by moderate concentrations of $\mathrm{Cu}$ (79 to 118 $\mu \mathrm{M})$ as cupric chloride. Copper-toxicity symptoms (Figs. 2 C-D and $3 \mathrm{~B}$ ) were not significantly increased with cupric chloride up to $157 \mu \mathrm{M} \mathrm{Cu}$. However, growth and $\mathrm{Cu}$-toxicity responses were similar for cuttings exposed to low and high concentrations of $\mathrm{Cu}$ as cupric chloride (Fig. 2 A-D), a result suggesting that the concentrations of cupric chloride evoking promotive effects had been exceeded. In general, microcuttings treated with low to moderate levels of cupric chloride (39 to $118 \mu \mathrm{M} \mathrm{Cu}$ ) appeared to be darker green and more robust (Fig. 3) than those of other treatments or the control. Significant increases in root and shoot growth when small amounts of chlorine were added were reported in early work on the essentiality of chlorine as a micronutrient (Gauch, 1972). Additional work is needed to determine if other species exhibit enhanced rooting and subsequent growth in response to added cupric chloride and if chlorine levels are optimal in WPM. Also, the effects of using $\mathrm{HCl}$ to equilibrate $\mathrm{pH}$ during media preparation are unknown.

Root and shoot growth were more inhibited by $\mathrm{Cu}$ added to the medium in the form of cupric acetate or cupric carbonate than as cupric sulfate or cupric chloride. Root regeneration (Figs. 1 C-D, 2A, and $3 \mathrm{C}-\mathrm{D}$ ), shoot growth, and root branching (Figs. 2B and $3 \mathrm{C}-\mathrm{D}$ ) were virtually eliminated and $\mathrm{Cu}$-toxicity symptoms (Figs. $2 \mathrm{C}-\mathrm{D}$ and $3 \mathrm{C}-\mathrm{D})$ drastically increased even at low concentrations of $\mathrm{Cu}$ as cupric acetate or cupric carbonate. Slightly greater toxicity symptoms were induced by cupric acetate than cupric carbonate with moderate to high $\mathrm{Cu}$ concentrations (Fig. $2 \mathrm{C}-\mathrm{D}$ ). Thus, the degree of $\mathrm{Cu}$ toxicity in vitro is affected by the accompanying anion, as it is in solution culture. Benchley, in Stiles (1961), reported that growth of Hordeum vulgare L. was stopped in a solution of $1 \mathrm{mg} \mathrm{Cu} / \mathrm{liter}(\approx 16 \mu \mathrm{M})$ supplied as cupric sulfate 


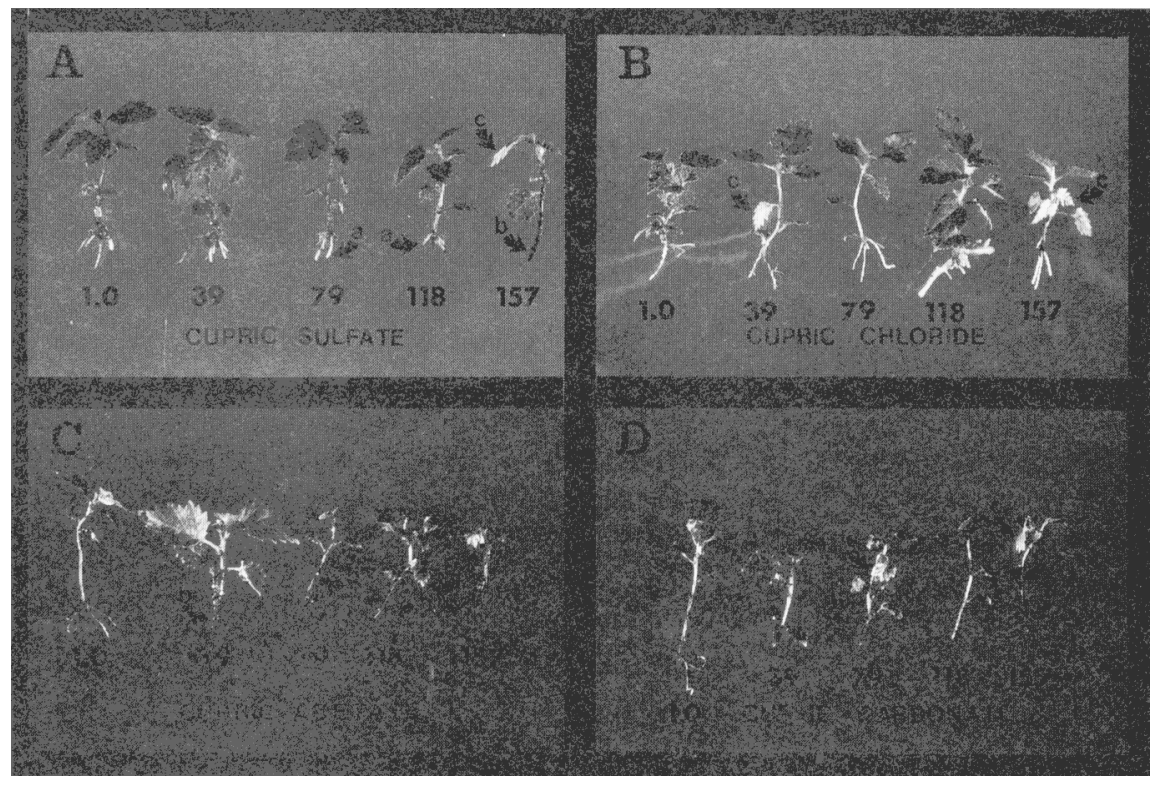

Fig. 3. Birch microcuttings after 28 days of exposure to woody plant medium containing 1.0 (control), 39,79,118, or $157 \mu$ Min the form of cupric sulfate (A), cupric chloride (B), cupric acetate (C), or cupric carbonate (D). Black arrows indicate possible Cu-toxicity symptoms such as thickened bulbous roots (a), necrotic stem tissue (b), and senescent leaves (c).
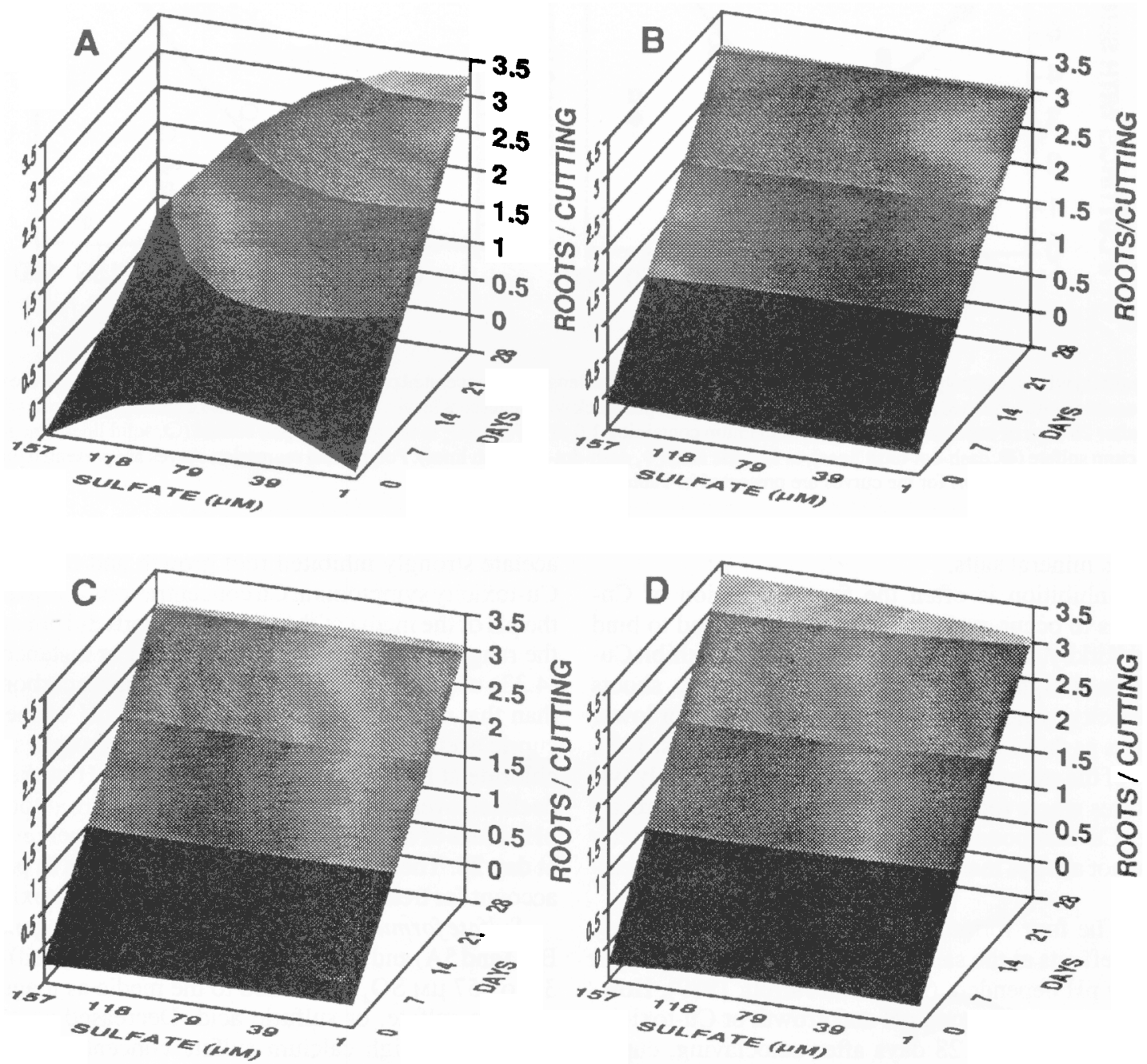

Fig. 4. Full quadratic response surfaces for the number of primary adventitious roots regenerated per birch cutting during 28 days of exposure to woody plant medium containing increased $\mathrm{SO}_{4}$ concentrations as cupric sulfate (A), magnesium sulfate (B), calcium sulfate (C), and sulfuric acid (D). Response surface equations are presented in Table 1. 

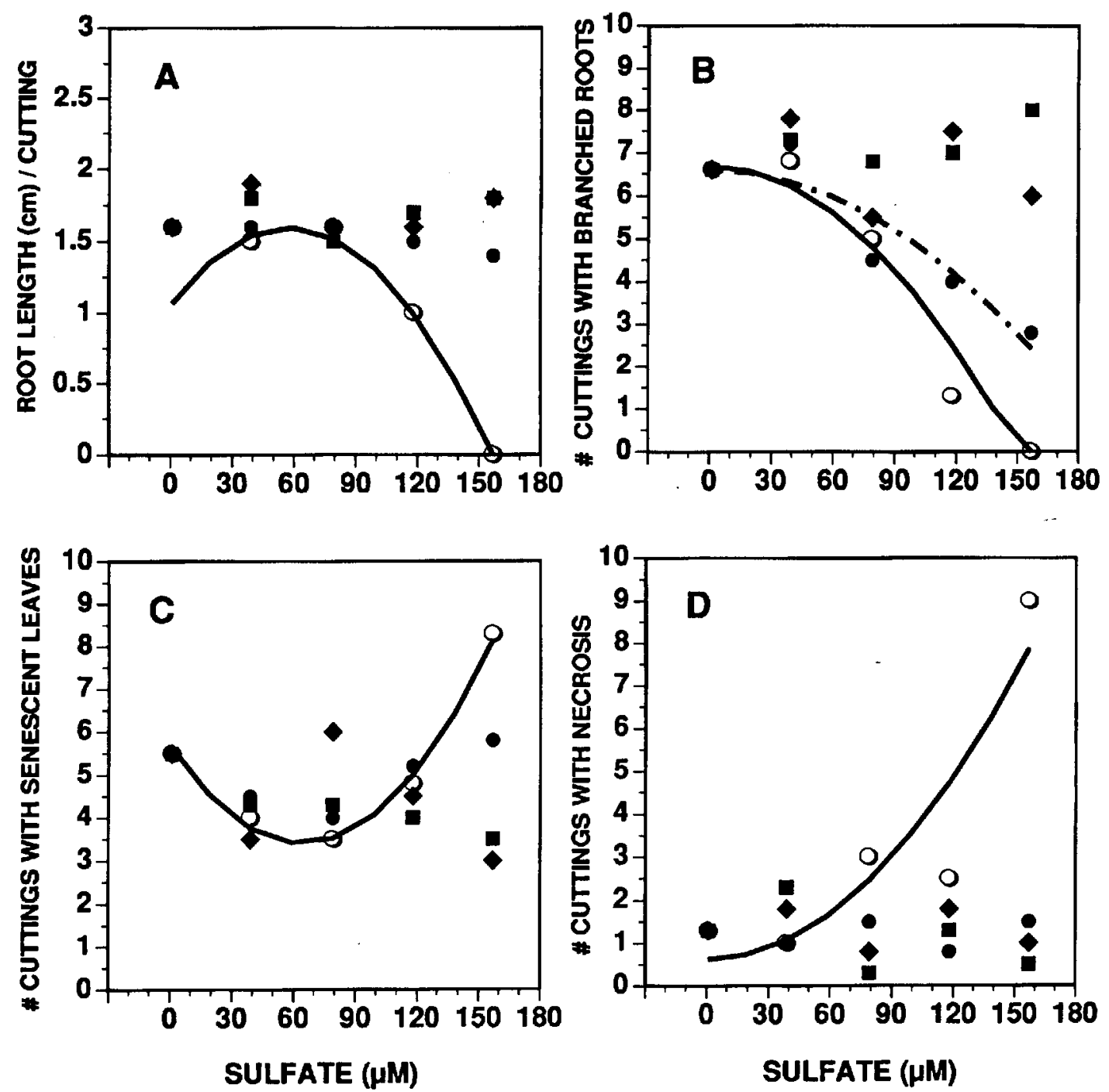

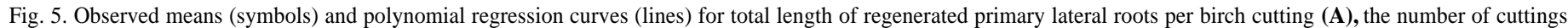

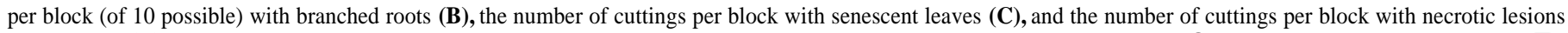

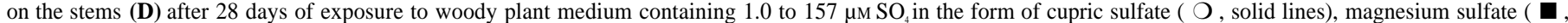

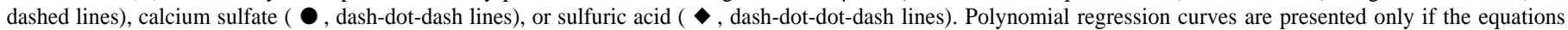
were significant $(P \leq 0.05)$. Equations for the curves are presented in Table 1 .

alone, but not in a solution containing $4 \mathrm{mg} \mathrm{Cu} / \mathrm{liter}(\approx 63 \mu \mathrm{M})$ as cupric sulfate plus mineral salts.

Root growth inhibition is often the first expression of $\mathrm{Cu}$ toxicity symptoms to occur, probably because roots tend to bind $\mathrm{Cu}$ (Mengel and Kirkby, 1982), while leaves and stems exhibit $\mathrm{Cu}-$ toxicity symptoms at higher concentrations. In this study, shoots exhibited $\mathrm{Cu}$-toxicity symptoms at exposure to the same or lower $\mathrm{Cu}$ concentrations as those that inhibited root growth (Figs. 1-3). Direct exposure of the stems to the $\mathrm{Cu}$ compounds in this study (vs. in-solution cultures where roots are often the only tissues directly exposed to the $\mathrm{Cu}$ compounds) may explain why $\mathrm{Cu}$-toxicity symptoms were not always manifested in the roots before appearing in the shoots.

Medium $p H$. The four formulations of $\mathrm{Cu}$ used in this study elicited different effects at the same $\mathrm{Cu}^{+2}$ concentrations. Copper uptake is strongly pH dependent (Allan and Jarrell, 1989). However, no consistent patterns among $\mathrm{pH}$ and growth or $\mathrm{Cu}$-toxicity symptoms were apparent. By 28 days after autoclaving, cupric chloride treatments had the highest $\mathrm{pH}(4.61$ at $39 \mu \mathrm{M} \mathrm{Cu})$ and the lowest $\mathrm{pH}(4.19$ at $157 \mu \mathrm{M} \mathrm{Cu})$ of any treatment. Yet no significant increases in $\mathrm{Cu}$-toxicity symptoms were noted over this $\mathrm{pH}$ range for these treatments (Fig. 2). While cupric carbonate and cupric acetate strongly inhibited root growth and induced considerable $\mathrm{Cu}$-toxicity symptoms at $\mathrm{Cu}$ concentrations $\geq 39 \mu \mathrm{M}$ (Figs. 1 and 2), the $\mathrm{pH}$ of the media of the two compounds did not correspond over the range of $\mathrm{Cu}$ concentrations tested. For instance, while the $\mathrm{pH}$ (4.33) of medium with $79 \mu \mathrm{M} \mathrm{Cu}$ as cupric carbonate was lower than that of many other treatments, the $\mathrm{pH}$ of media containing cupric acetate was closer to that of either cupric sulfate or cupric chloride at most $\mathrm{Cu}$ concentrations. The $\mathrm{pH}$ of the various media declined over the 28 days (from $\mathrm{pH} 5.3$ before autoclaving), but the $\mathrm{pH}$ values of all media were within 0.5 or fewer units of each other at day 28. These results suggest that changes in $\mathrm{pH}$ alone did not account for treatment effects on growth or $\mathrm{Cu}$-toxicity symptoms.

Sulfate formulations. Little change in root regeneration (Figs. 4 B-D and 5A) and shoot growth (data not presented) occurred when 39 to $157 \mu \mathrm{M} \mathrm{SO}_{4}$ was added to the media as magnesium sulfate, calcium sulfate, or sulfuric acid. Decreased root branching occurred with high calcium sulfate concentrations (Fig. 5B), although the effects were not as severe as with cupric sulfate. Copper-toxicity symptoms were not induced by increased concentrations of magnesium sulfate, calcium sulfate, or sulfuric acid 
Table 1. Formulas for quadratic response surfaces and polynomial regression equations used in Figs. 1, 2,4, and 5. In equations, $\mathrm{C}=$ concentration (in $\mu \mathrm{M}$ ) of $\mathrm{Cu}$ (Figs. 1 and 2) or sulfate (Figs. 4 and 5), D = days of exposure. All equations are significant at $P 0.05$.

\begin{tabular}{|c|c|c|c|}
\hline \multicolumn{2}{|c|}{ Fig. Treatment } & \multirow{2}{*}{$\begin{array}{l}\text { Equation } \\
\text { Roots/cutting }=-0.332+0.0148 \times C+0.102 \times D-0.0000990 \times C^{2}-0.0000434 \times C \times D+0.000823 \times D^{2}\end{array}$} & \multirow{2}{*}{\begin{tabular}{r|r}
$r^{2}$ \\
0.60
\end{tabular}} \\
\hline$\overline{1 A}$ & Cupric sulfate & & \\
\hline $1 \mathrm{~B}$ & Cupric chloride & Roots/cutting $=-0.288+0.00564 \times C+0.118 \times D-0.0000427 \times C^{2}+0.000169 \times C \times D-0.000292 \times D^{2}$ & 0.59 \\
\hline $1 \mathrm{C}$ & Cupric acetate & Roots/cutting $=0.147-0.0178 \times C+0.0725 \times D+0.000126 \times C^{2}-0.000631 \times C \times D+0.000328 \times D^{2}$ & 0.58 \\
\hline $1 \mathrm{D}$ & Cupric carbonate & Roots/cutting $=0.151-0.0186 \times C+0.0763 \times D+0.000130 \times C^{2}-0.000613 \times C \times D+0.000121 \times D^{2}$ & 0.57 \\
\hline \multirow[t]{4}{*}{$2 \mathrm{~A}$} & Cupric sulfate & Root length $(\mathrm{cm}) /$ cutting $=1.64+0.00482 \times \mathrm{C}-0.000100 \times \mathrm{C}^{2}$ & 0.45 \\
\hline & Cupric chloride & Root length $(\mathrm{cm}) /$ cutting $=1.64-0.153 \times \mathrm{C}+0.000313 \times \mathrm{C}^{2}-0.00000158 \times \mathrm{C}^{3}$ & 0.06 \\
\hline & Cupric acetate & Root length $(\mathrm{cm}) /$ cutting $=1.66-0.970 \times \mathrm{C}+0.000674 \times \mathrm{C}^{2}-0.00000221 \times \mathrm{C}^{3}$ & 0.70 \\
\hline & Cupric carbonate & Root length $(\mathrm{cm}) / \mathrm{cutting}=1.66-0.989 \times \mathrm{C}+0.000690 \times \mathrm{C}^{2}-0.00000225 \times \mathrm{C}^{3}$ & 0.71 \\
\hline \multirow[t]{4}{*}{ 2B } & Cupric sulfate & Cuttings with branched roots $=5.00-0.000242 \times \mathrm{C}^{2}$ & 0.71 \\
\hline & Cupric chloride & Cuttings with branched roots $=5.93+0.0340 \times \mathrm{C}-0.000268 \times \mathrm{C}^{2}$ & 0.29 \\
\hline & Cupric acetate & Cuttings with branched roots $=5.12-0.111 \times \mathrm{C}+0.000517 \times \mathrm{C}^{2}$ & 0.83 \\
\hline & Cupric carbonate & Cuttings with branched roots $=5.10-0.0997 \times \mathrm{C}+0.000446 \times \mathrm{C}^{2}$ & 0.80 \\
\hline \multirow[t]{3}{*}{$2 \mathrm{C}$} & Cupric sulfate & Cuttings with senescent leaves $=2.90+0.000170 \times \mathrm{C}^{2}$ & 0.35 \\
\hline & Cupric acetate & Cuttings with senescent leaves $=3.56+0.0752 \times \mathrm{C}-0.000230 \times \mathrm{C}^{2}$ & 0.78 \\
\hline & Cupric carbonate & Cuttings with senescent leaves $=3.51+0.0975 \times \mathrm{C}-0.000460 \times \mathrm{C}^{2}$ & 0.60 \\
\hline \multirow[t]{3}{*}{ 2D } & Cupric sulfate & Cuttings with necrotic stems $=0.759-0.0273 \times \mathrm{C}+0.000388 \times \mathrm{C}^{2}$ & 0.75 \\
\hline & Cupric acetate & Cuttings with necrotic stems $=0.244+0.126 \times \mathrm{C}-0.000416 \times \mathrm{C}^{2}$ & 0.88 \\
\hline & Cupric carbonate & Cuttings with necrotic stems $=1.68+0.0466 \times \mathrm{C}$ & 0.65 \\
\hline $4 \mathrm{~A}$ & Cupric sulfate & Roots/cutting $=-0.425+0.0179 \times \mathrm{C}+0.109 \times \mathrm{D}-0.000118 \times \mathrm{C}^{2}-0.000540 \times \mathrm{C} \times \mathrm{D}+0.000805 \times \mathrm{D}^{2}$ & 0.57 \\
\hline 4B & Magnesium sulfate & Roots/cutting $=-0.207-0.000340 \times \mathrm{C}+0.119 \times \mathrm{D}+0.00000545 \times \mathrm{C}^{2}-0.0000195 \times \mathrm{C} \times \mathrm{D}-0.000102 \times \mathrm{D}^{2}$ & 0.56 \\
\hline $4 \mathrm{C}$ & Calcium sulfate & Roots/cutting $=-0.188+0.000156 \times \mathrm{C}+0.111 \times \mathrm{D}-0.00000320 \times \mathrm{C}^{2}+0.00000734 \times \mathrm{C} \times \mathrm{D}+0.000170 \times \mathrm{D}^{2}$ & 0.61 \\
\hline 4D & Sulfuric acid & Roots/cutting $=-0.247+0.00120 \times \mathrm{C}+0.128 \times \mathrm{D}-0.00000880 \times \mathrm{C}^{2}+0.0000707 \times \mathrm{D} \times \mathrm{C}-0.000364 \times \mathrm{D}^{2}$ & 0.58 \\
\hline $5 \mathrm{~A}$ & Cupric sulfate & Root length $(\mathrm{cm}) /$ cutting $=1.05+0.0191 \times \mathrm{C}-0.000165 \times \mathrm{C}^{2}$ & 0.45 \\
\hline \multirow[t]{2}{*}{$5 B$} & Cupric sulfate & Cuttings with branched roots $=6.68-0.000298 \times \mathrm{C}^{2}$ & 0.69 \\
\hline & Calcium sulfate & Cuttings with branched roots $=6.58-0.000169 \times \mathrm{C}^{2}$ & 0.49 \\
\hline $5 \mathrm{C}$ & Cupric sulfate & Cuttings with senescent leaves $=5.70-0.0714 \times \mathrm{C}+0.000554 \times \mathrm{C}^{2}$ & 0.57 \\
\hline $5 \mathrm{D}$ & Cupric sulfate & Cuttings with necrotic stems $=0.622+0.000294 \times \mathrm{C}^{2}$ & 0.71 \\
\hline
\end{tabular}

(Fig. 5 C-D). Thus, we conclude that the cupric sulfate effects discussed above were caused by the $\mathrm{Cu}$ cation and not the $\mathrm{SO}_{4}$ anion. We do not know what portion of the growth and toxicity effects were due to $\mathrm{Cu}$ or the anions in the cupric chloride, cupric acetate, and cupric carbonate treatments in Expt. 1.

\section{Conclusions}

We have 'demonstrated that root growth and morphology responses of birch microcuttings depend on the formulation and concentration of $\mathrm{Cu}^{+2}$ used in the rooting medium. The stimulator effects of moderate concentrations of $\mathrm{Cu}$ added as cupric chloride suggest that cupric chloride may be a better formulation of $\mathrm{Cu}$ for use in rooting medium than cupric sulfate. Similar root growth and phytotoxicity symptoms were elicited with cupric acetate and cupric carbonate. Growth and phytotoxicity effects from cupric sulfate treatments were due to the $\mathrm{Cu}$ cation and not the sulfate anion. Consistent patterns among media $\mathrm{pH}$ and growth or phytoxicity responses to the applied treatments were not apparent.

\section{Literature Cited}

Allan, D.L. and W.M. Jarrell. 1989. Proton and copper adsorption to maize and soybean root cell walls. Plant Physiol. 89:823-832.

Gauch, H.G. 1972. Inorganic plant nutrition, Dowden, Hutchinson, and Ross, Stroudsburg, Pa. p. 488.

Lloyd, G. and B. McCown. 1980. Commercially-feasible micropropagation of mountain laurel, Kalmia latifolia, by use of shoot-tip culture. Intl. Plant Prop. Soc. Proc. 30:421-427.

Mengel, K. and E.A. Kirkby. 1982. Principles of plant nutrition. 3rd ed. Intl. Potash Inst. p. 655.

Murashige, T. and F. Skoog. 1962, A revised medium for rapid growth and bioassays with tobacco tissue cultures. Physiol. Plant. 15:473-497.

Neales, T.F. 1959. The boron requirement of flax roots grown in sterile culture. J. Expt. Bot. 10:426-436.

Ozolina, G. 1988. Growth of cereal roots at different levels of metal ions, 1.18. In: H. Fersson and E.L. McMichael (eds.). Abstracts of plant root and their environment. Intl. Soc. of Root Res. Symp., Uppsala, Sweden 21-26 Aug.

SAS Institute. 1988. SAS/STAT user's guide. release 6.03. SAS Institute, Cary, N.C. p. 1028.

Stiles, W. 1961. Trace elements in plants. Cambridge Univ. Press. p. 249. 